\section{Chirac's privatization programme reaches French science funding}

Paris

LATER this month a new bill, which aims to stimulate private patronage in a wide range of areas, from science and the natural environment to culture and sport, goes before the Senate (the French parliament's upper house). The "Patronage Bill" (Project de Loi de la Mécénat), put forward by Prime Minister Jacques Chirac and Minister of Economy, Finance and Privatization M Edouard Belladur, offers the now familiar carrot of increased tax incentives to private enterprises willing to donate part of their profits to recognized charitable trusts.

Sensitive to accusations that the bill is merely a device to camouflage cuts in spending on science and the arts, the government, in a senate report, insists that by seeking to stimulate private patronage, it is not shirking its responsibilities. An increase in the tax threshold certainly looks good on paper. If full use were made of the law, the cost to the government in lost revenue from taxation is estimated at 900 million francs ( $£ 90$ million). But figures provided in the report suggest that tax incentives may not be a very effective way to raise money. The new law will allow 0.3 per cent of gross turnover to be deductible from tax. But under the existing Finance Bill, private enterprises can already deduct up to 0.2 per cent of gross turnover by giving to charitable trusts and full use is not made of this concession. At national level, donations in 1986 represented only about 0.0001 per cent of total turnover.

Although the main thrust of the patronage bill is aimed at the arts, medical

\title{
India plans top-level spending on superconductor research
}

New Delhi

INDIA's prime minister, Rajiv Gandhi, has set up a a Cabinet-level committee under his own chairmanship to promote research related to ceramic superconductivity. This development is a measure of India's confidence that its researchers have much to contribute to (and that India stands to gain something from) the international excitement over the new phenomenon.

The members of the new panel include the ministers of science, finance and human resource development, the cabinet and finance secretaries and the heads of the science agencies supporting research on superconductivity. The committee's members also include Professor M. G. K. Menon, Gandhi's science adviser, Professor Yash Pal, chairman of the University Grants Commission, and four prominent industrialists.

Dr Vasant Gowariker, secretary of the Department of Science and Technology (DST), a member of the panel, says that the formation of the panel under the prime minister is a sign of the government's commitment to research in superconductivity. Gandhi has also set up a Programme Management Body under Professor C. N. I. Rao, the director of the Indian Institute of Science and Technology at Bangalore and chairman of the government's science advisory committee, to coordinate research at government and industrial laboratories. This body will have the executive power and financial muscle to pursue the project to its ultimate goal. Gowariker says that the equivalent of several million dollars has been allocat- ed to the coordinated programme.

Seven Indian research groups are engaged in superconductivity research: the Indian Institute of Science (Bangalore), the Tata Institute of Fundamental Research (Bombay), the Bhabha Atomic Research Centre (Trombay), the Madras Indian Institute of Technology, the Indira Gandhi Centre for Atomic Research (also at Madras), the National Physical Laboratory (New Delhi) and the National Chemical Laboratory (Pune). Each of these laboratories claims to have produced ceramic material superconducting up to $120 \mathrm{~K}$, and the National Physical Laboratory claimed room-temperature superconductivity just a week ago.

Despite excitement about the potential of the field, Gandhi's panel will have to talk tough to make the groups work together. The DST, referring to the "varying levels of accomplishment" at the different laboratories, says that these efforts "will come to nothing" unless there is a purposeful direction and a pooling of talent.

Unhappily, the atmosphere is already a little sour. Vulgar quarrels have erupted among the research groups, which are rivals. For example, the Bombay and Trombay groups, originally partners, have already split up. One scientist at the National Physical Laboratory asks how, if we have "rivalries within this institute", we can "expect cooperation on a national scale"

K.S.Jayaraman

The formula for the room-temperature superconductor was cited wrongly last week: the correct stoichiometry is $\mathrm{Y}_{2}$ (Ba,Sr) $\mathrm{Cu}_{3} \mathrm{O}_{*}$. charities will also benefit. One of these, the Fondation pour la Recherche Médicale, was spurred by the prospective bill to carry out a large-scale fund-raising drive and has already received positive replies from a number of major companies. Air Liquide, France's major manufacturer of industrial gases and parent company of a dozen subsidiaries, announced this week that it is to give FF6 million $(£ 600,000)$ to the foundation over the next three years. A memorandum issued by the company said that the money will be used "to stimulate progress in our understanding of the absorption of gases by the body. their transport, normal and pathological action and their use in biology and medicine".

Exactly how the money will be spent, within the terms of the donation, will be decided by the scientific advisory board of the foundation. M Gerard de Chavnac Lanzac, president of the foundation, said it was likely that up to 60 per cent will provide exchange bursaries for young researchers. Last year the foundation awarded 144 grants for French researchers to travel abroad and 50 to enable foreign researchers to visit French laboratories.

Although Air Liquide's donation will surely be welcome, meriting a full column of the right-wing daily Le Figaro, it cannot be considered over-generous within the provision of either the existing finance law or the proposed patronage bill. The gross turnover of one of the company's subsidiaries, Lipha, alone was over FF1,700 million ( $£ 170$ million).

Peter Coles

\section{Forest fire threatens Manchurian tiger} London

ChINA's voracious appetite for timber is unlikely to be dulled by the huge forest fire which blazed over 3.7 million hectares of Manchuria. Scientists fear that the loss of timber trees may mean enormous pressure on Chinese authorities to allow logging within internationally important nature reserves containing many rare species, including the Manchurian tiger.

The fire at one point threatened the Huzhong Nature Reserve, the third largest reserve in China, but the mobilization of more than 50,000 firefighters and a programme of cloud-seeding finally brought the blaze under control.

The stands of larch north and west of the Huzhong Reserve that were wiped out are relatively unimportant as far as rare species are concerned, but the timber available for China's rapid industrial expansion has been greatly reduced.

Scientists say that if logging is allowed in nature reserves, the Manchurian tiger could be exterminated; each of the 100 or so animals still in the wild needs more than $20 \mathrm{~km}^{2}$ of forest to survive. Kathy Johnston 